\title{
USING ISOTOPES OF DISSOLVED INORGANIC CARBON SPECIES AND WATER TO SEPARATE SOURCES OF RECHARGE IN A CAVE SPRING, NORTHWESTERN ARKANSAS, USA
}

\author{
UPORABA IZOTOPOV RAZTOPLJENEGA ANORGANSKEGA \\ OGLJIKA V VODI ZA LOČEVANJE VIROV NAPAJANJA IZVIRNE \\ JAME, SEVEROZAHODNI ARKANSAS, ZDA
}

\author{
Katherine J. KNIERIM ${ }^{1 *}$, Erik POLLOCK² \& Phillip D. HAYS ${ }^{3}$
}

\begin{abstract}
UDC 551.44:546.26.027^14(736.7)

Katherine J. Knierim, Erik Pollock ${ }^{\text {i }}$ Phillip D. Hays Using isotopes of dissolved inorganic carbon species and water to separate sources of recharge in a cave spring, northwestern Arkansas, USA

Blowing Spring Cave in northwestern Arkansas is representative of cave systems in the karst of the Ozark Plateaus, and stable isotopes of water $\left(\delta^{18} \mathrm{O}\right.$ and $\left.\delta^{2} \mathrm{H}\right)$ and inorganic carbon $\left(\delta^{13} \mathrm{C}\right)$ were used to quantify soil-water, bedrock-matrix water, and precipitation contributions to cave-spring flow during storm events to understand controls on cave water quality. Water samples from recharge-zone soils and the cave were collected from March to May 2012 to implement a multicomponent hydrograph separation approach using $\delta^{18} \mathrm{O}$ and $\delta^{2} \mathrm{H}$ of water and dissolved inorganic carbon $\left(\delta^{13} \mathrm{C}-\mathrm{DIC}\right)$. During baseflow, median $\delta^{2} \mathrm{H}$ and $\delta^{18} \mathrm{O}$ compositions were $-41.6 \%$ and $-6.2 \%$ for soil water and were $-37.2 \%$ and $-5.9 \%$ for cave water, respectively. Median DIC concentrations for soil and cave waters were $1.8 \mathrm{mg} / \mathrm{L}$ and $25.0 \mathrm{mg} / \mathrm{L}$, respectively, and median $\delta^{13} \mathrm{C}$-DIC compositions were $-19.9 \%$ and $-14.3 \%$, respectively. During a March storm event, $12.2 \mathrm{~cm}$ of precipitation fell over $82 \mathrm{~h}$ and discharge increased from 0.01 to $0.59 \mathrm{~m}^{3} / \mathrm{s}$. The isotopic composition of precipitation varied throughout the storm event because of rainout, a change of 50\% and $10 \%$ or $\delta^{2} \mathrm{H}$ and $\delta^{18} \mathrm{O}$ was observed, respectively. Although, at the spring, $\delta^{2} \mathrm{H}$ and $\delta^{18} \mathrm{O}$ only changed by approximately $3 \%$ and $1 \%$, respectively. The isotopic compositions of precipitation and pre-event (i.e., soil and bedrock matrix) water were isotopically similar and the two-component hydrograph separation was inaccurate, either overestimating $(>100 \%)$ or underestimating $(<0 \%)$ the precipitation contribution to the spring. During the storm event, spring DIC and $\delta^{13} \mathrm{C}-\mathrm{DIC}$ de-
\end{abstract}

\begin{abstract}
Izvleček
UDK 551.44:546.26.027*14(736.7)

Katherine J. Knierim, Erik Pollock ${ }^{\circ}$ Phillip D. Hays Uporaba izotopov raztopljenega anorganskega ogljika $v$ vodi za ločevanje virov napajanja izvirne jame, severozahodni Arkansas, ZDA

Jama Blowing Spring Cave v severozahodnem Arkansasu je tipični jamski sistem krasa na planoti Ozark. Stabilni izotopi vode $\left(\delta^{18} \mathrm{O}\right.$ in $\left.\delta^{2} \mathrm{H}\right)$ in anorganskega ogljika $\left(\delta^{13} \mathrm{C}\right)$ so bili uporabljeni za ovrednotenje, koliko med padavinskimi dogodki $\mathrm{k}$ pretoku izvira prispevajo voda iz prsti, kamnine in neposredne padavine, in za boljše razumevanje kakovosti izvirske vode. Za večkomponentni pristop ločevanja hidrograma $\mathrm{z} \delta^{18} \mathrm{O}$ in $\delta 2 \mathrm{H}$ vode in raztopljenega anorganskega ogljika $\left(\delta^{13} \mathrm{C}-\mathrm{DIC}\right)$ so bili med marcem in majem 2012 vzeti vzorci vode iz prsti in jame. Med bazičnim tokom je bila mediana $\delta 2 \mathrm{H}$ in $\delta 18 \mathrm{O}$ kompozicije $-41,6 \%$ in $-6,2 \%$ za vodo iz prsti ter $-37,2 \%$ in $-5,9$ \%o za jamsko vodo. Mediani DIC koncentracij sta bili $1,8 \mathrm{mg} / \mathrm{l}$ in $25,0 \mathrm{mg} / \mathrm{L}$, ter mediani kompozicije $\delta^{13} \mathrm{C}-\mathrm{DIC}-19,9 \%$ in $-14,3 \%$. Med nevihtnim dogodkom v marcu 2012, ko je v 82 urah padlo $12,2 \mathrm{~cm}$ padavin in se je pretok na izviru povečal z 0,01 na $0,59 \mathrm{~m}^{3} / \mathrm{s}$, se je izotopska sestava $\delta^{2} \mathrm{H}$ in $\delta^{18} \mathrm{O}$ v padavinah spreminjala za $50 \%$ oziroma $10 \%$. Kljub temu pa se je na izviru izotopska sestava $\delta^{2} \mathrm{H}$ in $\delta^{18} \mathrm{O}$ spreminjala le za približno $3 \%$ oziroma $1 \%$. Izotopske sestava padavin in vode iz prsti in kamnine pred nevihtnim dogodkom je bila podobna, zato je bilo izotopsko ločevanje dveh komponent hidrograma netočno in je bodisi precenjevalo (> $100 \%$ ) ali podcenjevalo $(<0 \%)$ prispevek padavine $\mathrm{k}$ izvirski vodi. Med nevihtnim dogodkom so se vrednosti DIC in $\delta^{13} \mathrm{C}$-DIC na izviru zmanjšale na najmanj $8,6 \mathrm{mg} / \mathrm{l}$ in $-16,2 \%$. Ob predpostavki, da je prispevek padavin ničen, je bilo ugotovljeno, da je prispevek vode iz prsti med $23-72 \%$ pretoka na izviru. Čeprav je predpostavka
\end{abstract}

\footnotetext{
${ }^{1}$ Environmental Dynamics Program, University of Arkansas, Fayetteville, AR, (p) 479-575-6633, (f) 479-575-3469,

e-mal:kknierim@uark.edu

${ }^{2}$ University of Arkansas Stable Isotope Lab, University of Arkansas, Fayetteville, AR, (f) 479-575-3251, e-mal: epolloc@uark.edu

${ }^{3}$ U.S. Geological Survey, Arkansas Water Science Center, Fayetteville, AR; Department of Geosciences, University of Arkansas,

Fayetteville, AR, (f) 479-575-3469, e-mal: pdhays@usgs.gov

* corresponding author
}

Received/Prejeto: 15.2.2013 
creased to a minimum of $8.6 \mathrm{mg} / \mathrm{L}$ and $-16.2 \%$, respectively. If the contribution from precipitation was assumed to be zero, soil water was found to contribute between 23 to $72 \%$ of the total volume of discharge. Although the assumption of negligible contributions from precipitation is unrealistic, especially in karst systems where rapid flow through conduits occurs, the hydrograph separation using inorganic carbon highlights the importance of considering vadose-zone soil water when analyzing storm chemohydrographs.

Keywords: carbon, stable isotopes, cave, hydrograph, Arkansas. o zanemarljivih prispevkih padavin nerealna, zlasti v kraških sistemih, kjer prihaja do hitrega pretoka skozi kanale, ločitev hidrograma $\mathrm{z}$ anorganskim ogljikom poudarja pomembnost upoštevanja vode iz vadozne cone in prsti pri analizi kemohidrogramov med padavinskimi dogodki.

Ključne besede: ogljik, stabilni izotopi, jama, hidrogram, Arkansas.

\section{INTRODUCTION}

Blowing Spring is the focal point of a park located in Bella Vista, Arkansas, which lies on the Springfield Plateau in the Ozark Plateaus (Fig. 1). The spring has experienced degraded water quality since the 1990's, including transient, elevated E. coli levels with nitrate and chloride concentrations increasing over time. The spring discharges from a cave in the Boone Formation, a Mississippian-aged limestone with up to $50 \%$ chert that hosts abundant karst features including caves, springs, and dissolution-enlarged fractures and conduits (Adamski et al. 1995). The proposed research aimed to quantify sources of water to the cave stream across the range of hydrologic conditions to assess contaminant effects (bacteria, organic carbon, nu- trients) on cave and spring water quality. Much research has focused on water quality at springs, but for this study sampling soil above the cave provided access to vadose zone groundwater and sampling within the cave allowed for direct sampling of bedrock matrix waters, enabling a more complete understanding of water-quality controls. This labor-intensive method monitored karst recharge as the water traveled from the atmosphere, through the soil and epikarst zones, into karst conduits, and discharged at the spring - providing a more thorough assessment of geochemical evolution along groundwater flow paths. Stable isotopes are a valuable tool for characterizing flow paths and biogeochemical processing in anisotropic karst

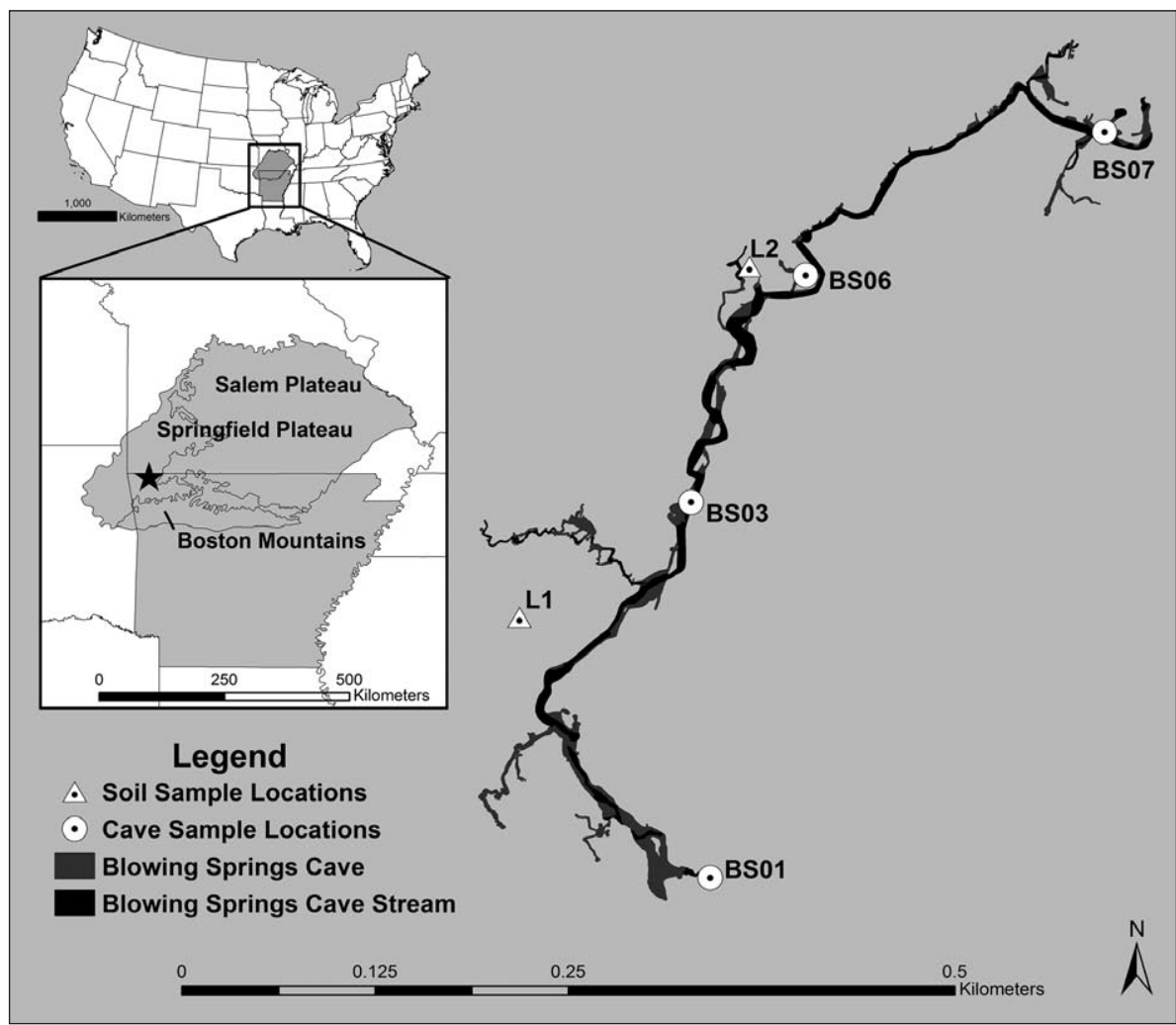

Fig. 1: Blowing Springs Cave (star) is located in northwestern Arkansas on the Springfield Plateau, which is one of the Ozark Plateaus. The cave stream begins at a sump near sampling site BSO7 and flows to the spring at BS01. Site BSO6 is in a side passage where drip water collects in a pool (approximately $3 \mathrm{~m}$ by $3 \mathrm{~m}$ wide and $0.2 \mathrm{~m}$ deep). Land use above the cave is mixed forest and suburban development. Cave mapping completed by the Boston Mountain Grotto. 
systems (Panno et al. 2001; Trček et al. 2006), and this research applied stable isotope techniques to caves.

Stable isotopes of water $\left(\delta^{2} \mathrm{H}\right.$ and $\left.\delta^{18} \mathrm{O}\right)$ are commonly used as natural tracers because (in the absence of evaporation) the isotopes behave conservatively, meaning that changes in the isotopic composition of water are due to mixing of water sources, as opposed to biogeochemical reactions (Sklash et al. 1976). Marked differences in individual storm isotopic compositions - imparted by seasonal variation in temperature, humidity, vapor sources, storm tracks, rainout, and other factors (Clark \& Fritz 1997; Gibson et al. 2008; Harvey 2001) - often cause storm-event water to be isotopically distinct from water stored in the recharge zone, because mixing in the phreatic zone dampens the isotopic signal of individual storm events providing a time-averaged composition for the stored water (Buttle 1994). Characterizing local precipitation is important in groundwater studies because the isotopic composition of precipitation varies over space and time, and precipitation is ultimately the water source for most aquifers (Harvey 2001; Simpkins 1995).

Hydrograph separations are mixing models used to quantify source-water contributions to stream and spring flow during storm events and generally include three components; precipitation, soil water, and groundwater (Lee \& Krothe 2003; Ogunkoya \& Jenkins 1993; Rice \& Hornberger 1998). Hydrograph separations that use a combination of conservative $\left(\delta^{2} \mathrm{H}\right.$ and $\left.\delta^{18} \mathrm{O}\right)$ and non-conservative $\left(\delta^{13} \mathrm{C}\right)$ tracers can separate water stored in the recharge zone prior to a storm event (preevent water) from water delivered during a storm event (event water) and account for changes in water chemistry along flow paths (Kendall et al. 2001; Sklash \& Farvolden 1979). Most mixing models do not adequately account for hydrodynamic dispersion during water transport, but some amount of mixing between sources must occur along the flow path (Jones et al. 2006); therefore, hydrograph separations should not be considered to discretely separate water sources that are conservatively partitioned between zones, but reflect the concomitant effects of water movement from and through those zones.
In karst settings, hydrograph separations have been applied to quantify the proportion of quick flow (represented by precipitation) entering springs during storm events (Lakey \& Krothe 1996; Lee \& Krothe 2001; Lee \& Krothe 2003; Long 2009). Surface features such as sinkholes and losing stream segments and bedrock characteristics such as fractures and dissolution-enlarged conduits allow surface water to rapidly enter the subsurface. Although the preferential pathways allow for rapid infiltration, vadose water (either soil or epikarst) still contributes substantial volumes $(>50 \%)$ to storm flow discharge (Doctor et al. 2006; Lakey \& Krothe 1996; Lee \& Krothe 2001; Lee \& Krothe 2003; Trček et al. 2006). According to Lakey and Krothe (1996), the delivery mechanism for this water is rapid displacement of water within or in direct contact with conduits, so that pre-event water is quickly transported to karst springs. These techniques have focused on storm-flow hydrographs from springs (Lee \& Krothe 2001) and only limited work interpreting the effects of conduit geometry on water geochemistry has been completed either at springs (Luhman et al. 2012) or within the conduit of a cave (Raeisi et al. 2007).

In this research, a three-component hydrograph separation (Lee \& Krothe 2001) was completed using $\delta^{18} \mathrm{O}$ and $\delta^{2} \mathrm{H}$ of water and the concentration and isotopic composition of dissolved inorganic carbon $\left(\delta^{13} \mathrm{C}-\mathrm{DIC}\right)$ to separate the contributions of precipitation $\left(\mathrm{Q}_{\mathrm{R}}\right)$, soil or vadose water $\left(\mathrm{Q}_{\mathrm{S}}\right)$, and bedrock matrix or groundwater $\left(Q_{B}\right)$ to the cave stream during storm events. In this conceptual model, soil water represents the vadose zone (not separately accounting for epikarst water) and the cave stream at baseflow represents bedrock matrix water. The epikarst is a very important zone for water storage and biogeochemical processing in karst settings (Peterson et al. 2002; Laincz 2011), but because $\mathrm{n}$ tracers can separate $n+1$ sources, the addition of epikarst source water would require an additional tracer. By quantifying the discharge of the cave stream, the flux of contaminants can be calculated and related directly to the proportions of quick-flow $\left(Q_{R}\right)$ and diffuse flow $\left(Q_{S}\right.$ and $\left.Q_{B}\right)$.

\section{STUDY SITE}

The Ozark Plateaus, which include the Boston Mountains, Springfield Plateau, and Salem Plateau, extend through Missouri, Kansas, Oklahoma, and Arkansas and are one of the major karst terrains in North America (Adamski et al. 1995; Fig. 1). The karst landscape in the Ozarks of northwestern Arkansas is characterized by chert regolith mantle overlying Paleozoic limestone, dolomite, sandstone, and shale. Orthogonal fracture sets in the carbonate rocks provide pathways for water migration, causing dissolution-enlarged fractures, conduits, caves, sinking streams, and sinkholes and creating a landscape with direct connections between surface water and groundwater 
(Brahana 1997). The primary threat to water quality is nutrients and bacteria because of the karst topography and agriculture (Adamski et al. 1995), which is dominated by poultry and cattle production (U.S. Department of Agriculture 2007). Best Management Practices for reducing contaminant transport into the vulnerable karst waters have been employed, although the long-term effects of these practices are not fully understood (Davis et al. 2000). Therefore, research that quantifies contaminant transport along groundwater flow paths is vital in the Ozarks to better protect karst waters.

Northwestern Arkansas has a temperate climate; average annual air temperature is $15.6^{\circ} \mathrm{C}$ and precipitation is approximately $109 \mathrm{~cm}$ per year (Adamski et al. 1995). During 2012, northwestern Arkansas experienced a drought; especially during the warmer summer months (Simeral 2013). For example, $16.4 \mathrm{~cm}$ of rain fell during June, July, and August, compared to historical averages of $30 \mathrm{~cm}$ for the summer months (National Oceanic and Atmospheric Administration 2009). Recharge to the Springfield Plateau includes precipitation and stream piracy (Brahana 1997). Groundwater levels generally reflect surface topography (Adamski et al. 1995), but, as is characteristic in karst aquifers, ground- and surface-water divides do not always coincide (Brahana 1997). Karst features are more common in the pure carbonate lithologies, compared to units with higher proportions of chert and insoluble clays (Adamski et al. 1995; Brahana 1997). Caves are typically less than $150 \mathrm{~m}$ long and less than $30 \mathrm{~m}$ deep in the Ozarks of Arkansas because of the nearly horizontal bedding and the insoluble nature of the clay-rich regolith mantle (Taylor et al. 2009).

Blowing Spring Cave includes $2.4 \mathrm{~km}$ of mapped passage in the St. Joe Limestone Member of the Boone Formation (Fig. 1). The branching cave passage is dominated by a cave stream passage, which originates at a sump (BS07). The recharge-area boundaries for the cave stream have not yet been identified. Using the normalized baseflow method (Brahana 1997) and a baseflow at the spring of $0.009 \mathrm{~m}^{3} / \mathrm{s}$, the recharge area is estimated to be between 2.9 to $6.1 \mathrm{~km}^{2}$. Meteoric water is recharged through the chert regolith mantle and into the shallow Springfield Plateau Aquifer, which includes the Boone Formation (Adamski et al. 1995), and precipitation enters Blowing Spring Cave by either percolation through the soil/regolith mantle above the cave or via the undefined flow paths of the cave stream sump. Soils above the cave are predominantly extremely gravelly silt loam, $1.8 \mathrm{~m}$ thick, with a high capacity to transmit water, from approximately 5 to $15 \mathrm{~cm} / \mathrm{hr}$ (Natural Resources Conservation Service 2012). Chert beds in the Boone Formation can be observed in the cave ceiling and cause lateral groundwater flow due to local perching. Discrete points of drip water enter the cave passage where these chert layers are breached by fractures; discharge at these drip-water points increases following storm events. Site BS06 is one example where drip water enters a domed, side passage and collects in a pool, before flowing into the main cave stream. Site BS01 is located where the cave stream discharges at the surface as a spring and tributary to Little Sugar Creek, which defines local base level.

\section{METHODS}

\section{SAMPLE COLLECTION AND ANALYSIS}

A stage-discharge relation was developed using stage readings from a $90^{\circ} \mathrm{V}$-notch weir constructed $50 \mathrm{~m}$ downstream from the spring and accuracy checked using the cross-section method (Rantz 1982) and a MarchMcBirney Flo-Mate $2000^{m}$. Continuous stage and temperature readings were recorded using $\mathrm{HOBO}^{\circ} \mathrm{U} 20$ transducers located in the weir pool and at the spring. Weather conditions were recorded using a $\mathrm{HOBO}^{\circledR}$ Micro Station with barometric pressure and temperature sensors and a tipping-bucket rain gauge, located $1 \mathrm{~km}$ west of the spring. Collection of stage, discharge, and weather data began in February 2012.

Water samples were collected from two lysimeters (L1 and L2) installed in the soil zone above the cave (approximately $0.75 \mathrm{~m}$ depth), three locations in the cave
(BS03, BS06, BS07), and the spring (BS01). The boundaries of the recharge area for the cave stream are not defined, so the dry, headwater valleys above the cave provided the best means to sample soil water that infiltrates through the regolith and enters Blowing Spring Cave as dripwater. Sampling goals included bi-monthly sampling (i.e., every other week) to monitor background (baseflow) conditions for soil and cave waters and more frequent storm-event sampling to quantify differences in baseflow versus storm-event geochemistry. Preliminary, intermittent cave sampling was initiated June 2011 and consistent bi-monthly sampling began in March 2012.

Water samples pumped from the soil lysimeters or collected from the cave were analyzed for stable isotopes of water $\left(\delta^{2} \mathrm{H} / \delta^{18} \mathrm{O}\right.$, collected in 60 -mL HDPE bottles), DIC $\left(\delta^{13} \mathrm{C}\right.$-DIC, filtered through Supor ${ }^{\circledast} 0.45-\mu \mathrm{m}$ filters 
into 40-mL total organic carbon vials without headspace and preserved with $40 \mu \mathrm{L}$ of $3.6 \mathrm{M}$ sodium azide to stop biologic activity), and major anions (collected in 125-mL HDPE bottles). The limited volumes of soil water (especially during dry surface conditions) required that water samples for isotopic analysis be immediately transferred to the smallest practical vial size to minimize headspace and decrease the potential for evaporation. Physical parameters ( $\mathrm{pH}$, specific conductance, and temperature) were monitored in the cave stream during sample collection (small water volumes prevented measurement of physical parameters in soil water). Samples were kept on ice until transported to an environmental chamber $\left(4^{\circ} \mathrm{C}\right)$ at the University of Arkansas Stable Isotope Laboratory (UASIL) in Fayetteville, Arkansas.

Precipitation samples were collected at the $\mathrm{HOBO}^{\circ}$ Micro Station for $\delta^{2} \mathrm{H} / \delta^{18} \mathrm{O}$ analysis. A funnel directed precipitation through looped tubing and into 1-L HDPE sample bottle, which was also connected to an overflow bottle filled with deionized water to prevent evaporation. Samples were collected in $60-\mathrm{mL}$ to $250-\mathrm{mL}$ HDPE bottles (depending on precipitation volume, to minimize headspace). Precipitation samples were collected daily for most rain events (composite samples) or, during larger rain events, samples were collected periodically throughout the storm.

Hydrogen and oxygen stable isotope ratios $\left(\delta^{2} \mathrm{H} /\right.$ $\delta^{18} \mathrm{O}$ ) were measured using a high-temperature reduction unit interfaced to a Delta plus XP isotope ratio mass spectrometer (IRMS TCEA, Thermo Scientific) at UASIL. Samples were loaded into $1.5-\mathrm{mL}$ auto-sampler vials and $1 \mu \mathrm{L}$ of sample was injected into the TCEA. The furnace on the TCEA was operated at $1,425^{\circ} \mathrm{C}$ with a glassy carbon reactor. A 5a-mol-sieve gas chromatography column (GCC) separated the resulting $\mathrm{H}_{2}$ and $\mathrm{CO}$ gases, which were admitted to the IRMS via a con Flo III interface (Gehre et al. 2004). Samples were normalized to the Vienna Standard Mean Ocean Water (VSMOW) scale following Nelson (2000) using three isotopically distinct standards analyzed multiple times throughout the run. The precision of the hydrogen measurement was $\pm 1.0 \%$ and the precision for oxygen was $\pm 0.2 \%$ o.

DIC samples were analyzed for concentration and isotopic composition $\left(\delta^{13} \mathrm{C}\right.$-DIC) at the Colorado Plateau Stable Isotope Laboratory in Flagstaff, Arizona on a Total Organic Carbon Analyzer (Aurora OI 1010 College Station, Texas) interfaced to an IRMS (Delta plus XL ThermoQuest Finnigan Bremen, Germany) following a procedure modified from St-Jean (2003). DIC was acidified with phosphoric acid to form carbon dioxide $\left(\mathrm{CO}_{2}\right)$, which was then carried via helium through a "scrubber unit" and GCC to remove nitrogen interferences and into the IRMS (Knierim 2009).
Isotopic compositions were reported using $\delta$ notation:

$\delta_{\text {sample }}(\% 0)=\frac{R_{\text {sample }}-R_{\text {standard }}}{R_{\text {standard }}} \times 1000$

Eqn. 1

where $\delta$ represents the isotopic system and $\mathrm{R}$ is the ratio of the heavy to light isotope $\left({ }^{13} \mathrm{C} /{ }^{12} \mathrm{C},{ }^{2} \mathrm{H} /{ }^{1} \mathrm{H}\right.$, or $\left.{ }^{18} \mathrm{O} /{ }^{16} \mathrm{O}\right)$ for the sample relative to a standard. The Vienna Peedee Belemnite was used as the standard for $\delta^{13} \mathrm{C}-\mathrm{DIC}$ and VSMOW was used for $\delta^{2} \mathrm{H} / \delta^{18} \mathrm{O}$ (Coplen 1996).

Major anion geochemistry was analyzed at the Arkansas Water Resources Center (AWRC) Water Quality Laboratory in Fayetteville, Arkansas using ion chromatography; a Dionex DX-120 with an IonPac AS4A-SC analytical column measured fluoride, bromide, chloride, nitrate, and sulfate (AWRC 2008). Only the chloride (Cl) data will be discussed.

\section{DATA ANALYSIS}

Following methods by Lee and Krothe (2001), a threecomponent hydrograph separation was completed to quantify precipitation $\left(\mathrm{Q}_{\mathrm{R}}\right)$, soil water $\left(\mathrm{Q}_{\mathrm{S}}\right)$, and bedrock matrix water $\left(Q_{B}\right)$ contributions to the cave stream during storm events $\left(\mathrm{Q}_{\mathrm{M}}\right)$. Soil and bedrock-matrix waters together represent the pre-event component of storm flow $\left(\mathrm{Q}_{\mathrm{p}}\right)$ and $\mathrm{Q}_{\mathrm{R}}$ represents storm-event water that has traveled rapidly along macropores and dissolution conduits. To separate $\mathrm{Q}_{\mathrm{P}}$ and $\mathrm{Q}_{\mathrm{R}}$ from $\mathrm{Q}_{\mathrm{M}}$, a two-component mixing model using $\delta^{2} \mathrm{H}$ and $\delta^{18} \mathrm{O}$ of water was solved first (Lakey \& Krothe 1996):

$Q_{R}=Q_{M}\left[\frac{\delta_{M}-\delta_{P}}{\delta_{R}-\delta_{P}}\right]$

Eqn. 2

where $Q_{M}$ is the total discharge of the cave stream at the spring (BS01). The isotopic composition of storm event water at BS01 $\left(\delta_{\mathrm{M}}\right)$, pre-event water from the soil and cave during baseflow conditions $\left(\delta_{\mathrm{p}}\right)$, and precipitation $\left(\delta_{\mathrm{R}}\right)$ were determined using either hydrogen or oxygen, to check for consistency in the technique (Lakey \& Krothe 1996). Cl was used as a secondary tracer and Equation 2 was completed using $\mathrm{Cl}$ concentration, not the stable isotope ratio of $\mathrm{Cl}$.

Once the proportions of $Q_{P}$ and $Q_{R}$ were determined, $Q_{p}$ was separated into $Q_{S}$ and $Q_{B}$ components using DIC concentration (C) and isotopic composition $(\delta)$ in a three-component mixing model (Lee \& Krothe 2001):

$Q_{S}=Q_{M}\left[\frac{C_{M} \delta_{M}-\frac{Q_{R}}{Q_{M}}\left(C_{R} \delta_{R}\right)+C_{B} \delta_{B}\left(\frac{Q_{R}}{Q_{M}}-1\right)}{C_{S} \delta_{S}-C_{B} \delta_{B}}\right]$ Eqn. 3 
$Q_{B}=Q_{M}-Q_{R}-Q_{S}$

Eqn. 4

where the isotopic composition of storm event water at BS01 $\left(\delta_{\mathrm{M}}\right)$, soil water $\left(\delta_{\mathrm{S}}\right)$, the cave stream at baseflow
$\left(\delta_{\mathrm{B}}\right)$, and precipitation $\left(\delta_{\mathrm{R}}\right)$ were determined using $\delta^{13} \mathrm{C}-$ DIC. For the full derivation of the previous equations, see Lakey and Krothe (1996) and Lee and Krothe (2001).

\section{RESULTS}

\section{METEORIC WATER LINE AND ISOTOPES OF WATER $\left(\delta^{2} \mathrm{H}\right.$ AND $\left.\delta^{18} \mathrm{O}\right)$}

Median compositions for $\delta^{2} \mathrm{H}$ and $\delta^{18} \mathrm{O}$ of precipitation were $-30.1 \%$ and $-4.7 \%$, respectively $(n=41)$, for the time period between October 2011 and September 2012. A local meteoric water line (LMWL) for precipitation (not normalized for amount) was defined by first-order regression as (Fig. 2):

$$
\delta^{2} H=6.7 \delta^{18} O+1.5 \%
$$

Eqn. 5

Median soil water $\delta^{2} \mathrm{H}$ and $\delta^{18} \mathrm{O}$ compositions were $-41.6 \%$ and $-6.2 \%$, respectively $(\mathrm{n}=11)$. Median cave water $\delta^{2} \mathrm{H}$ and $\delta^{18} \mathrm{O}$ compositions were $-37.2 \%$ and $-5.7 \%$, respectively, for all samples (baseflow and storm flow, $\mathrm{n}=83$ ). During baseflow conditions, median cave water $\delta^{2} \mathrm{H}$ and $\delta^{18} \mathrm{O}$ compositions were $-37.2 \%$ and $-5.9 \%$, respectively $(\mathrm{n}=59)$. Collectively, the median $\delta^{2} \mathrm{H}$ and $\delta^{18} \mathrm{O}$ compositions for pre-event water (i.e., combing soil and cave baseflow samples) were $-37.4 \%$ and $-5.9 \%$, respectively, ( $\delta_{\mathrm{P}}$ in Eqn. 2 ).

\section{DISSOLVED INORGANIC CARBON (DIC)}

Soil-water DIC had a median concentration of $1.8 \mathrm{mg} / \mathrm{L}$ $\left(\mathrm{C}_{\mathrm{S}}\right.$ in Eqn. $\left.3, \mathrm{n}=8\right)$ and median $\delta^{13} \mathrm{C}-\mathrm{DIC}$ composition of $-19.9 \%$ ( $\delta_{\mathrm{s}}$ in Eqn. $\left.3, \mathrm{n}=8\right)$. Soil DIC concentration and isotopic composition were generally lower and lighter, respectively, than DIC in the cave (Fig. 3). Cave-water DIC had a median concentration of $24.6 \mathrm{mg} / \mathrm{L}(\mathrm{n}=56)$ and median $\delta^{13} \mathrm{C}$-DIC composition of $-14.5 \% 0(\mathrm{n}=56)$ for all samples (including baseflow and storm flow). During baseflow conditions, median DIC concentration and $\delta^{13} \mathrm{C}$-DIC composition were $25.0 \mathrm{mg} / \mathrm{L}(\mathrm{n}=43)$ and $-14.3 \% 0(\mathrm{n}=43)$, respectively, in the cave. Site BS06 is a drip-water pool (separate from the cave stream), so DIC concentrations and compositions were also calculated for the cave stream sites only (BS01, BS03, and BS07); DIC in the cave stream had a median concentration of $25.2 \mathrm{mg} / \mathrm{L}(\mathrm{n}=35)$ and median $\delta^{13} \mathrm{C}$-DIC composition of $-14.5 \% 0(\mathrm{n}=35)$. Additionally, site BS07 is closest to the sump (i.e., the source of water for the cave stream), and median DIC concentration for BS07 (during baseflow) was $27.8 \mathrm{mg} / \mathrm{L}(\mathrm{n}=8)$ and median $\delta^{13} \mathrm{C}$-DIC composition was $-14.3 \% 0(\mathrm{n}=8)$.

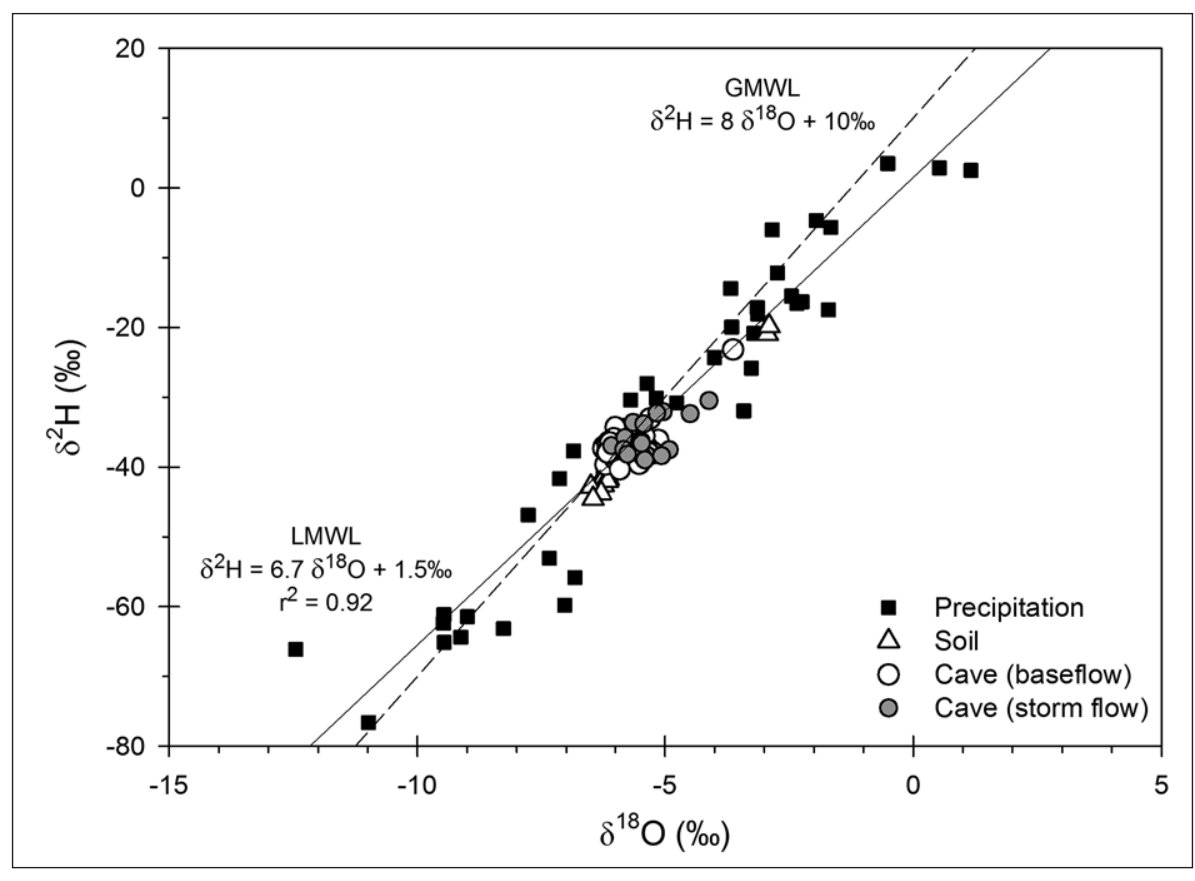

Fig. 2: A Local Meteoric Water Line (LMWL) for northwestern Arkansas was developed for comparison to the Global Meteoric Water Line (GMWL; Craig 1961). 


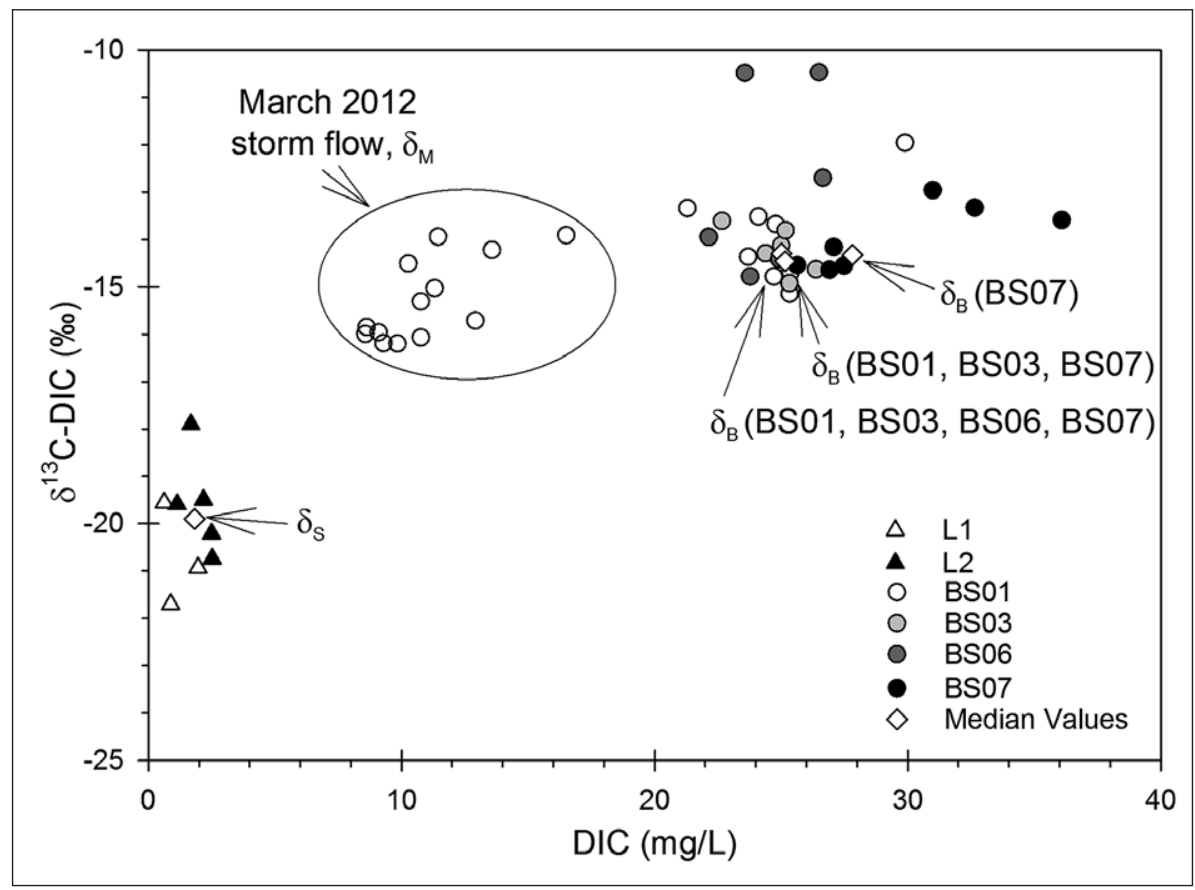

Fig. 3: The cave stream tended to have higher DIC concentrations and heavier $\delta^{13} \mathrm{C}-\mathrm{DIC}$ compositions than the soil. Storm samples at BSO1 represent mixed flow $\left(\delta_{M}\right)$ from a combination of soil $\left(\delta_{S}\right)$ and bedrock-matrix $\left(\delta_{B}\right) w a-$ ters.

\section{HYDROGRAPH SEPARATIONS}

During a March 2012 storm event, $12.2 \mathrm{~cm}$ of precipitation fell over $82 \mathrm{~h}$ and discharge increased from 0.01 to $0.59 \mathrm{~m}^{3} / \mathrm{s}$ in $59 \mathrm{~h}$ (Fig. 4). The isotopic composition of precipitation varied throughout the storm event because of rainout; for example, $\delta^{2} \mathrm{H}$ decreased from -37.7 to $-66.2 \%$ over $28 \mathrm{~h}$ and a similar pattern occurred for $\delta^{18} \mathrm{O}$. Although, at the spring, $\delta^{2} \mathrm{H}$ and $\delta^{18} \mathrm{O}$ only changed by approximately $3 \%$ and $1 \%$, respectively (Fig. 4). Precipitation from the storm event was normalized for amount because throughout the event the isotopic composition of precipitation became more depleted in ${ }^{2} \mathrm{H}$ and ${ }^{18} \mathrm{O}$ (Fig. 5). Therefore, the values for $\delta_{\mathrm{R}}$ in Equation 2 changed throughout the storm event (Fig. 5) and ranged between -37.2 and $-45.4 \%$ for $\delta^{2} \mathrm{H}$ and -6.7 and $-7.6 \%$ for $\delta^{18} \mathrm{O}$ (Tab. 1). Solving for Equation 2, the two-component mixing model either overestimated $(>100 \%)$ or underestimated $(<0 \%)$ the contribution from $Q_{R}$ (Tab. 1).

The two-component mixing model was completed a second time using $\mathrm{Cl}$ concentration to provide an estimate of contribution from precipitation, as the mixing model using stable isotopes was inaccurate. Median $\mathrm{Cl}$ was $3.2 \mathrm{mg} / \mathrm{L}(\mathrm{n}=5)$ in the soil and $6.3 \mathrm{mg} / \mathrm{L}(\mathrm{n}=23)$ in the cave during baseflow. Collectively, median $\mathrm{Cl}$ during baseflow for all sites (soil and cave) was $6.2 \mathrm{mg} / \mathrm{L}$ $\left(\delta_{\mathrm{p}}\right.$ in Eqn. 2). Precipitation samples were only analyzed for $\delta^{2} \mathrm{H}$ and $\delta^{18} \mathrm{O}$, so historical, annual $\mathrm{Cl}$ concentration from the National Atmospheric Deposition Program's (NADP) National Trends Network were used for nearby sites in northern Arkansas (AR27), southeastern Kansas (KS07), southern Missouri (MO50), and eastern Okla- homa (OK08 and OK99). Precipitation from the NADP samples had median $\mathrm{Cl}$ of $0.138 \mathrm{mg} / \mathrm{L}\left(\delta_{\mathrm{R}}\right.$ in Eqn. 2 ) for the time period between 1980 and 2011, depending on the individual site (NADP 2007). Using $\mathrm{Cl}, \mathrm{Q}_{\mathrm{R}}$ was found to vary with time and contribute between 6 and $43 \%$ of the total discharge throughout the March storm event, depending on the point along the hydrograph (Tab. 1). For example, $Q_{R}$ contributed the maximum amount to $\mathrm{Q}_{\mathrm{M}}$ on March 21, 2012 at 3:35 p.m. (Tab. 1), approximately $43 \mathrm{~h}$ after precipitation began.

During the storm event, DIC decreased to a minimum of $8.6 \mathrm{mg} / \mathrm{L}$ from a baseflow concentration of 29.9 $\mathrm{mg} / \mathrm{L}$ and $\delta^{13} \mathrm{C}$-DIC decreased to $-16.2 \%$ from a baseflow composition of $-12.0 \%$ (Fig. 4). If $\mathrm{Q}_{R}$ is ignored because the two-component mixing model using $\delta^{2} \mathrm{H} /$ $\delta^{18} \mathrm{O}$ was inaccurate, the three-component mixing model (Eqns. 3 and 4) becomes a two-component mixing model, separating $Q_{P}$ into $Q_{S}$ and $Q_{B}$ using the following equations:

$Q_{S}=Q_{M}\left[\frac{C_{M} \delta_{M}-C_{B} \delta_{B}}{C_{S} \delta_{S}-C_{B} \delta_{B}}\right]$

Eqn. 6

$Q_{M}=Q_{P}=Q_{B}+Q_{S}$

Eqn. 7

The precipitation terms $\left(C_{R}\right.$ and $\left.\delta_{R}\right)$ are eliminated from Equation 3. Solving for Equations 6 and 7 using DIC concentrations and isotopic composition at all cave water sites during baseflow (BS01, BS03, BS06, and $\mathrm{BS} 07), \mathrm{Q}_{\mathrm{S}}$ contributed 23 to $69 \%$ of the total discharge (Tab. 2, Fig. 6). If site BS06 is not included, $\mathrm{Q}_{\mathrm{S}}$ contrib- 


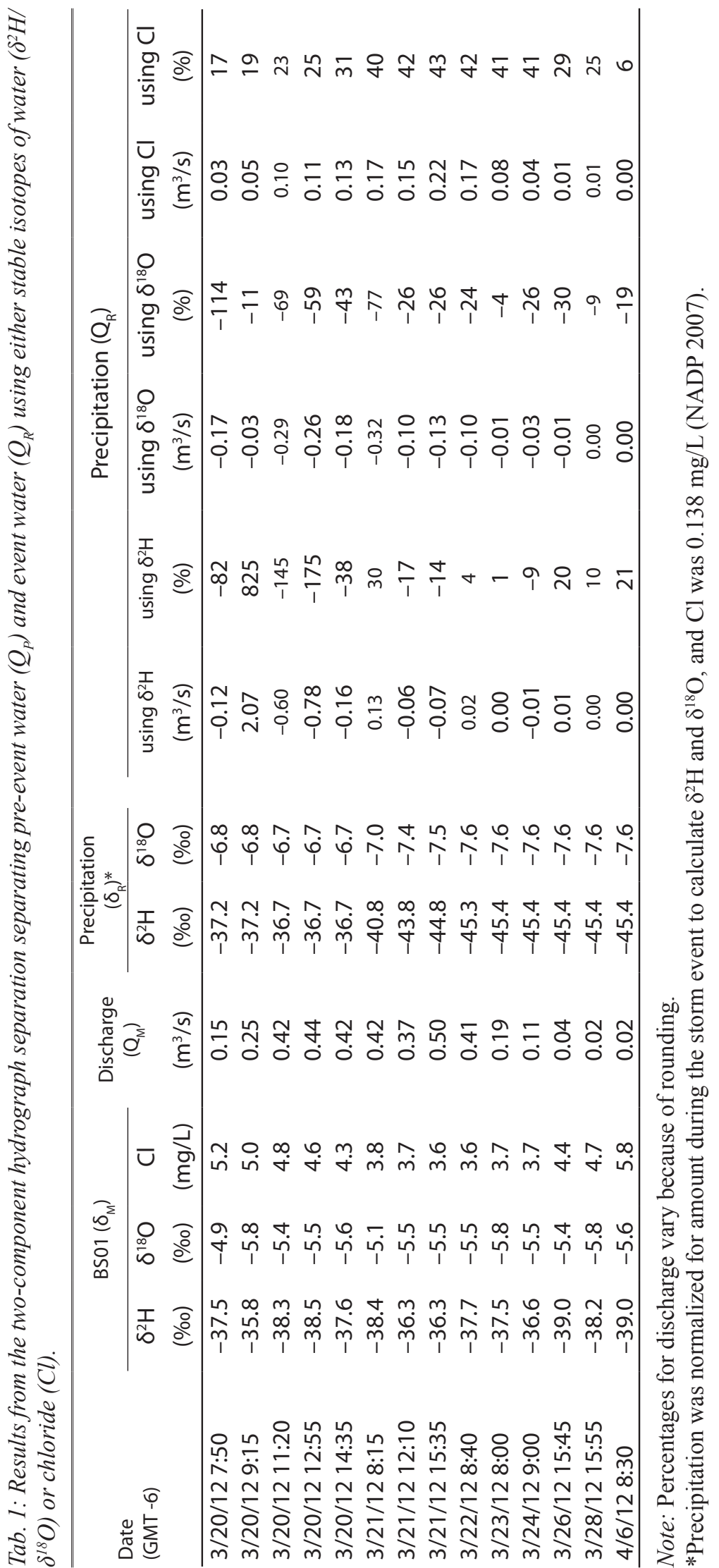

uted 24 to $69 \%$ of the total discharge (Tab. 2). If only site BS07 is used, then $\mathrm{Q}_{\mathrm{S}}$ contributed 32 to $72 \%$ of the total discharge (Tab. 2).

If $Q_{R}$ was found to contribute between 6 and $43 \%$ of the total flow (based on the two-component mixing model using $\mathrm{Cl}$ ), then the remaining portion of storm flow (i.e., the contribution from $Q_{P}$ ) can be separated into $Q_{S}$ and $Q_{B}$ to solve Equation 4 (using the percentages calculated previously from Eqns. 6 and 7, Tab. 2). Similar to the previous discussion, different values for $\mathrm{C}_{\mathrm{B}}$ and $\delta_{\mathrm{B}}$ were used, depending on the location in the cave (Fig. 3). Using DIC concentration and isotopic composition at all cave water sites during baseflow, $\mathrm{Q}_{\mathrm{S}}$ contributed 20 to $50 \%$ of the total discharge (Tab. 2, Fig. 6). If site $\mathrm{BS} 06$ is not included, $\mathrm{Q}_{\mathrm{S}}$ contributed 22 to $50 \%$ of the total discharge (Tab. 2). If only site BS07 is used, then $\mathrm{Q}_{S}$ contributed 28 to $53 \%$ of the total discharge (Tab. 2). 


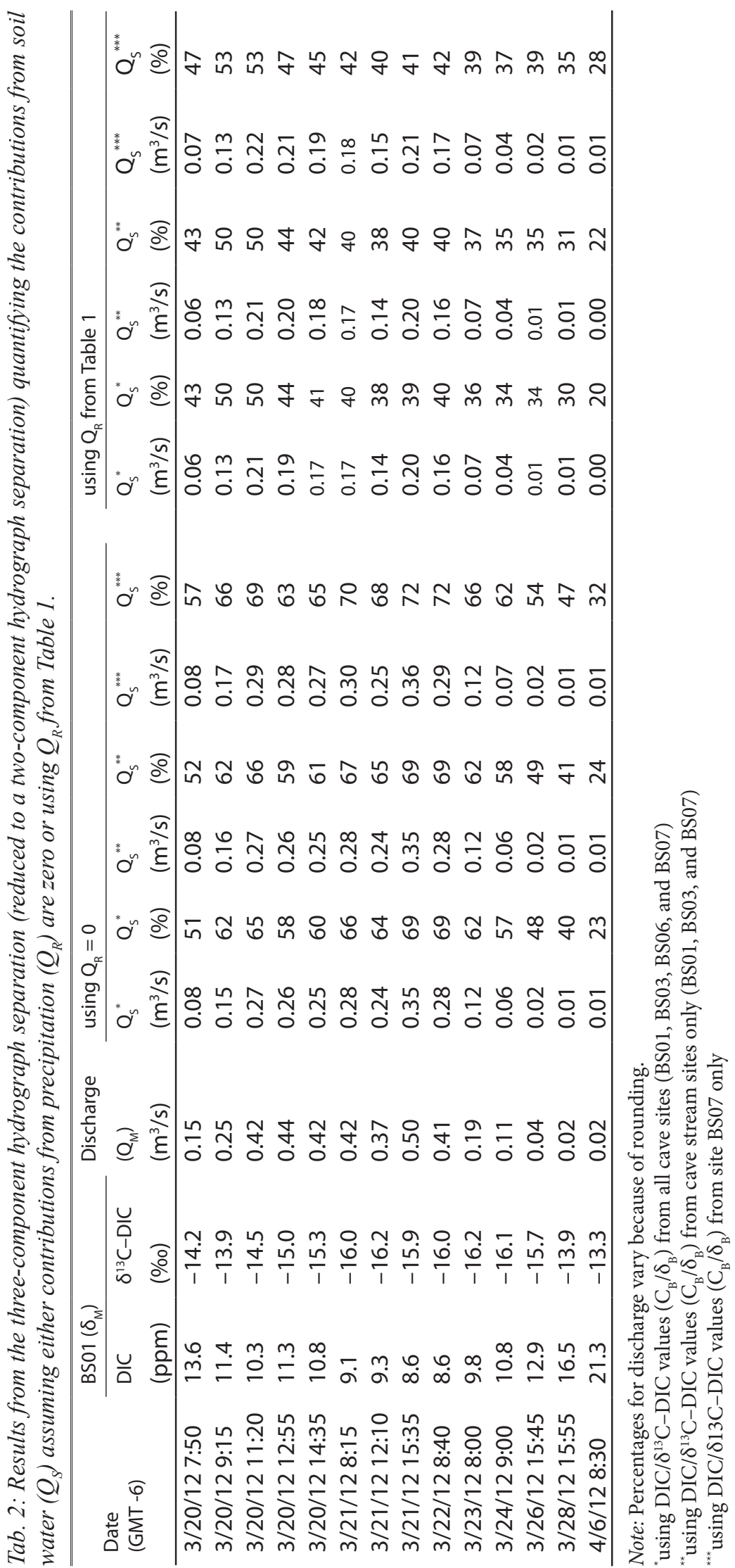




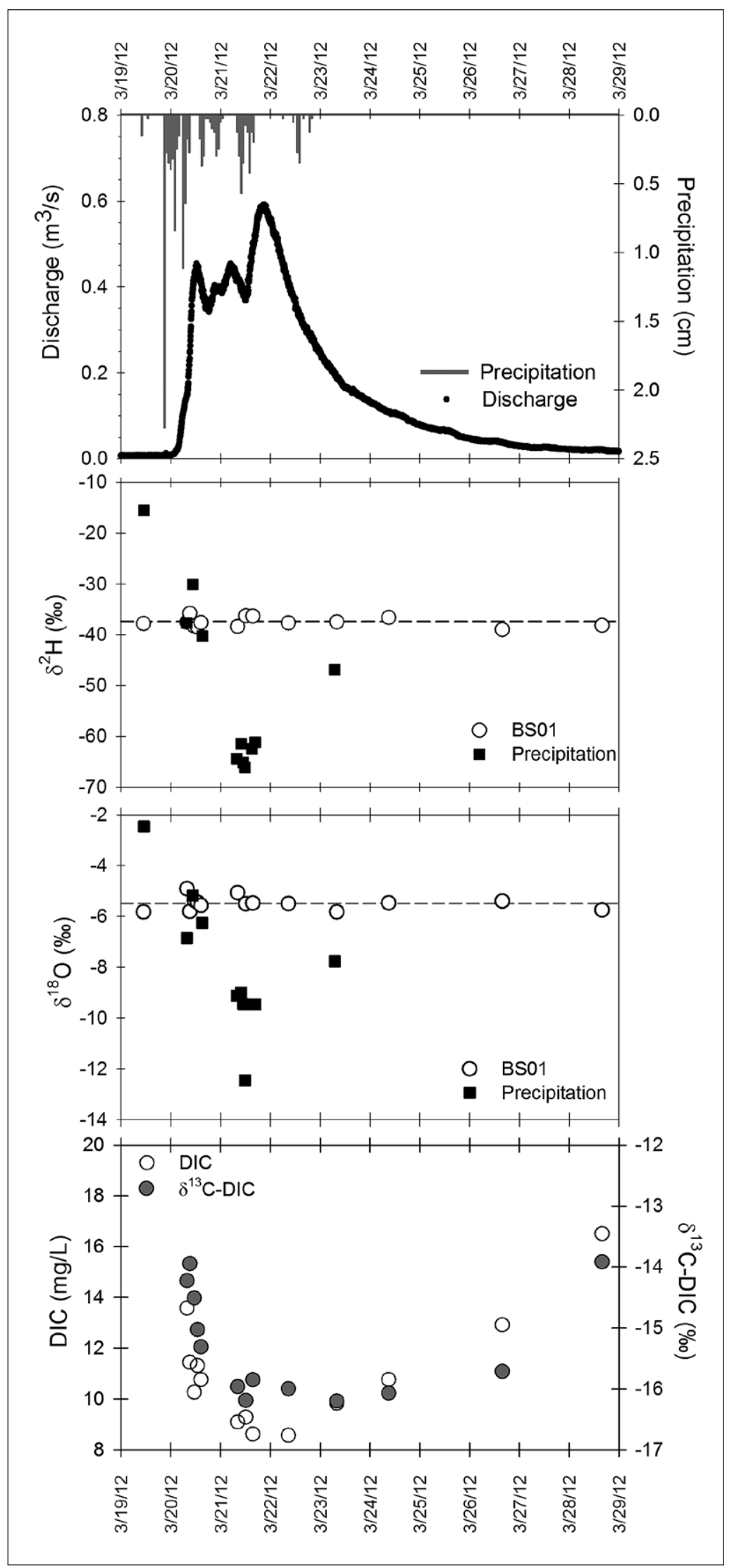

Fig. 4: During a storm event in March 2012, $12.2 \mathrm{~cm}$ of precipitation fell over $82 \mathrm{hrs}$. Baseflow conditions (from March $16^{\text {th }}$ 2012) are shown with a dashed line for $\delta^{2} H$ and $\delta^{18} \mathrm{O}$. DIC was $29.9 \mathrm{mg} / \mathrm{L}$ and $\delta^{13} \mathrm{C}-\mathrm{DIC}$ was $-12.0 \%$ on March $16^{\text {th }} 2012$. 

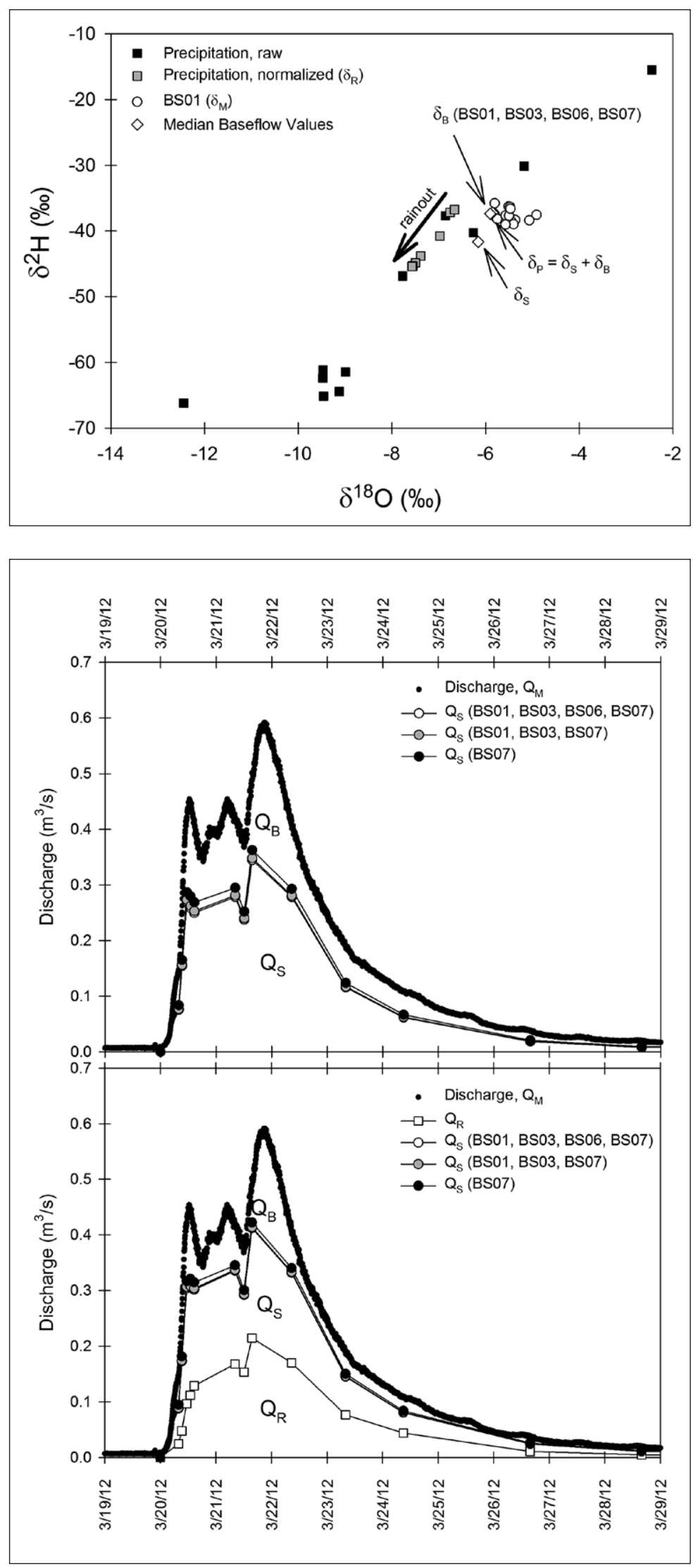

Fig. 5: The isotopic composition of precipitation $\left(\delta_{R}\right)$ was normalized for precipitation amount (arrow). The isotopic composition of pre-event water $\left(\delta_{p}\right)$ includes soil water $\left(\delta_{S}\right)$ and bedrock matrix water from the cave $\left(\delta_{B}\right)$.
Fig. 6: Hydrograph separations for the March 2012 storm event quantifying the contributions from rain $\left(Q_{R}\right)$, soil water $\left(Q_{S}\right)$, and bedrock matrix water from the cave $\left(Q_{B}\right)$. 


\section{DISCUSSION}

The LMWL for northwestern Arkansas (Fig. 2) had a lower slope and y-intercept than the global meteoric water line (Craig 1961) similar to meteoric water lines for the northern Great Plains (Harvey 2001; Harvey \& Welker 2000; Simpkins 1995). Values for deuterium excess (d defined as $\delta^{2} \mathrm{H}-8 \delta^{18} \mathrm{O}$; Dansgaard 1964) are primarily controlled by the relative humidity at the time of vapor formation (Merlivat \& Jouzel 1979) and would be between 3 and 15\% for transported water vapor that has not undergone secondary processes (Harvey 2001). Smaller $\mathrm{d}$ values $(\mathrm{d}<3 \%$ ) generally correspond to water that has experienced secondary evaporation and larger $\mathrm{d}$ values $(\mathrm{d}>15 \%$ ) with water vapor that has secondary moisture added to it (Harvey 2001). For precipitation from northwestern Arkansas, $\mathrm{d}$ varied between -7 and $35 \%$, with a median value of $8 \%$. Most of the $d$ values less than 3 occurred during the warmer, summer months and secondary evaporation may have occurred as the precipitation fell through the warm, dry atmosphere. The LMWL was developed during a drought and period of above-average temperatures for northwestern Arkansas (Simeral 2013), which may cause a lower slope and y-intercept than for a LMWL generated during times more representative of long-term local climatic conditions. Moisture deficits during the spring and summer months have been observed during historical, decadelong droughts in the mid-continent (Burnette \& Stahle 2013) and future projections predict drier conditions for the southern Great Plains during the summer months (Patricola \& Cook 2013). Therefore, understanding karst hydrologic processes during periods of moisture deficit will likely be important for future protection of karst water resources.

Both soil and cave water tended to cluster around $\delta^{18} \mathrm{O}$ of $-6 \%$ (Fig. 2), representative of the regional average for precipitation (Clark \& Fritz 1997). Generally, soil water is more enriched in ${ }^{2} \mathrm{H}$ and ${ }^{18} \mathrm{O}$ than precipitation because of evaporative enrichment of heavier isotopes in the residual soil water (Gibson et al. 2008). In the soil above Blowing Springs Cave, soil water tended to be depleted in ${ }^{2} \mathrm{H}$ and ${ }^{18} \mathrm{O}$ compared to cave water (Fig. 2). Note that the two heavier soil-water compositions $\left(\sim-3 \%\right.$ for $\left.\delta^{18} \mathrm{O}\right)$ were collected immediately following a precipitation event and reflect the composition of meteoric water that has mixed with soil water. Therefore, water entering the soil zone, which is ultimately meteoric water, must have some finite residence time in the soil zone to be considered "pre-event" water. Residence times (or, in comparison, transit times) for soil water vary based on the type of soil, intensity of precipitation, and topography (Tetzlaff et al. 2011). The soils above
Blowing Springs Cave have a high capacity to transmit water (Natural Resources Conservation Service 2012), which would imply a short residence time and fast transit time in or through the soil zone, although exact times have not yet been constrained for this study site.

The isotopic difference between median soil water and median cave water (during baseflow) was approximately $4.4 \%$ and $0.3 \%$ for $\delta^{2} \mathrm{H}$ and $\delta^{18} \mathrm{O}$, respectively, and cave water exerts a stronger control on the isotopic composition of $\delta_{\mathrm{p}}$ (Fig. 5), likely because of sampling bias as more cave water samples were collected $(n=59$ for cave at baseflow) compared to soil water $(\mathrm{n}=11)$. The isotopic variation between precipitation from the March 2012 storm event and the pre-event water was approximately $8.0 \%$ and $1.7 \%$ for $\delta^{2} \mathrm{H}$ and $\delta^{18} \mathrm{O}$, respectively, at the end of the storm event (Fig. 5). The isotopic composition of precipitation became lighter throughout the storm event because of rainout (Fig. 5); the process of the vapor mass becoming progressively lighter during the storm event as the heavier isotopes $\left({ }^{2} \mathrm{H} /{ }^{18} \mathrm{O}\right)$ are partitioned into the liquid phase with a progressive, concomitant effect on continued precipitation (Clark \& Fritz 1997). Most of the precipitation fell overnight on March $19^{\text {th }}$ (Fig. 4) and this composite sample $(-37.7 \%$ and $-6.9 \%$ for $\delta^{2} \mathrm{H}$ and $\delta^{18} \mathrm{O}$, respectively) was isotopically similar to the pre-event water (Fig. 5). Additionally, the storm-flow samples at BS01 $\left(\delta_{\mathrm{M}}\right)$ were enriched in ${ }^{18} \mathrm{O}$ compared to pre-event water $\left(\delta_{\mathrm{p}}\right)$. These two factors contributed to the two-component hydrograph separation using $\delta^{2} \mathrm{H} / \delta^{18} \mathrm{O}$ either over- or under-estimating the contribution from precipitation to the spring and disagreement between solving Equation 2 for $\delta^{2} \mathrm{H}$ versus $\delta^{18} \mathrm{O}$ (Tab. 1). Other studies have found that the quick-flow component (or precipitation) to karst springs accounted for 10 to $40 \%$ of total discharge (Lakey \& Krothe 1996; Lee \& Krothe 2001; Long 2009; Mahler \& Garner 2009; Trček et al. 2006).

If the contributions from $Q_{R}$ were ignored, which is unrealistic in karst systems where rapid flow through soil macropores (Iqbal \& Krothe 1995) and conduits occur (Lee \& Krothe 2003), the hydrograph separation using DIC (Eqns. 3 and 4) was completed as a two-component mixing model (Eqns. 6 and 7) to separate $Q_{p}$ into $Q_{S}$ and $Q_{B}$, which provides an initial estimate for contributions from water stored in the recharge zone. Quantifying the proportions of pre-event water is useful in karst settings because changing contributions from the unsaturated versus saturated zones can control spring geochemistry during baseflow and storm events (Peterson et al. 2002). Storm-flow samples from BS01 $\left(\mathrm{C}_{\mathrm{M}} / \delta_{\mathrm{M}}\right)$ plotted between soil water $\left(\mathrm{C}_{\mathrm{S}} / \delta_{\mathrm{S}}\right)$ and cave water $\left(\mathrm{C}_{\mathrm{B}} / \delta_{\mathrm{B}}\right)$, meaning that 
the two-component mixing model should reflect realistic mixing conditions during the storm event (Fig. 3). Using different values for $\mathrm{C}_{\mathrm{B}} \delta_{\mathrm{B}}$, depending on the location in the cave stream (BS01, BS03, or BS07) or drip pool (BS06), changed the contribution from $\mathrm{Q}_{\mathrm{S}}$ by 4 to 9\% throughout the storm event (Tab. 2). Cave-stream water at BS07 during baseflow had similar $\delta^{13} \mathrm{C}-\mathrm{DIC}$ compositions to all cave stream samples $(\sim-14.3 \%$ o), but higher DIC concentrations (Fig. 3). Therefore, solving Equations 6 and 7 using $C_{B}$ from BS07 caused the lowest estimations for the contributions from $Q_{B}$, or increased the contribution from $\mathrm{Q}_{\mathrm{S}}$ (Fig. 6; Tab. 2).

The two-component mixing model using $\mathrm{Cl}$ estimated that $\mathrm{Q}_{\mathrm{R}}$ contributed up to $43 \%$ of the total storm flow, similar to other karst spring hydrograph separations (Mahler \& Garner 2009), which decreased the estimated contribution from $\mathrm{Q}_{S}$ and $\mathrm{Q}_{\mathrm{B}}$. For example, if $\mathrm{C}_{\mathrm{B}} / \delta_{\mathrm{B}}$ values for only site BS07 at baseflow were used, then $Q_{B}$ contributed between 16 and $61 \%$ of the total storm flow (down from 28 to $68 \%$ when $\mathrm{Q}_{\mathrm{R}}$ was assumed to be zero). Similar to the previous discussion, using DIC concentration and $\delta^{13} \mathrm{C}-\mathrm{DIC}$ composition from only site BS07 to complete Equations 6 and 7 caused the greatest estimations for contributions from $\mathrm{Q}_{\mathrm{S}}$ (Fig. 6; Tab. 2). Noting that Equation 3 was not completed for this discussion, as the two-component hydrograph separation using $\delta^{2} \mathrm{H}$ versus $\delta^{18} \mathrm{O}$ was inaccurate, the two-component hydrograph separation using $\mathrm{Cl}$ was completed to provide constraints on the pre-event contribution to storm flow. Therefore, including $\mathrm{Q}_{\mathrm{R}}$ as a third component in Equation 3 would provide a third source of water (i.e., precipitation) to mixed flow that has lower DIC concentrations and $\delta^{13} \mathrm{C}$-DIC compositions enriched in ${ }^{13} \mathrm{C}$ compared to the other sources, based on equilibrium exchange and fractionation between atmospheric $\mathrm{CO}_{2}$ and precipitation (Clark \& Fritz 1997; Lee \& Krothe 2001). For example, Lee and Krothe (2001) found that DIC concentration in precipitation was $2 \mathrm{mg} / \mathrm{L}$ and $\delta^{13} \mathrm{C}-\mathrm{DIC}$ composition was calculated to be $-7 \%$. Therefore, completion of the mixing model using Equations 6 and 7 likely overestimated the contribution from $Q_{S}$ because $C_{S}$ and $C_{R}$ would have similar DIC concentrations compared to $C_{B}$. Future expansion of the mixing model, including completing Equation 3 using temperature- and $\mathrm{pH}$-dependent values for $C_{R}$ and $\delta_{R}$ at Blowing Spring, may find that the bedrock-matrix contributes greater volumes of water during storm events.

\section{CONCLUSIONS}

The two-component hydrograph separation using $\delta^{2} \mathrm{H} /$ $\delta^{18} \mathrm{O}$ of water to separate pre-event water $\left(Q_{p}\right.$, soil and cave-stream water at baseflow) and event water $\left(Q_{R}\right.$, precipitation) either overestimated $(>100 \%)$ or underestimated $(<0 \%)$ the contribution from $\mathrm{Q}_{\mathrm{R}}$ because (1) precipitation (when normalized for amount) was isotopically similar to the pre-event water and (2) storm flow at BS01 $\left(\delta_{\mathrm{M}}\right)$ was outside the range of the two end-members (Fig. 5). Therefore, an additional source of water enriched in ${ }^{18} \mathrm{O}$ may need to be considered. If $\mathrm{Q}_{\mathrm{R}}$ was ignored, $\mathrm{Q}_{S}$ was found to contribute 23 to $72 \%$ of the total discharge, depending on the values used for $\mathrm{C}_{\mathrm{B}} / \delta_{\mathrm{B}}$ (Tab. 2). If $\mathrm{Q}_{\mathrm{R}}$ was calculated using $\mathrm{Cl}, \mathrm{Q}_{\mathrm{S}}$ was found to contribute 20 to $53 \%$ of the total discharge, again depending on the values used for $C_{B} / \delta_{B}$ (Tab. 2). Is the variation in contributions from $Q_{S}$ or $Q_{B}$ important (Fig. 6), when using different DIC concentrations and isotopic compositions $\left(\mathrm{C}_{\mathrm{B}} / \delta_{\mathrm{B}}\right)$ from along the cave stream reach? At each time-step (or sampling point along the hydrograph), the difference in contributions from $\mathrm{Q}_{S}$ or $\mathrm{Q}_{\mathrm{B}}$ between (1) all cave water at baseflow (BS01, BS03, BS06, and BS07) and (2) only cave water at BS07 (closest to the sump source of the cave stream) averaged $5 \%$ when $Q_{R}$ was assumed to be zero or
4\% when $\mathrm{Q}_{\mathrm{R}}$ was calculated using $\mathrm{Cl}$ (Tab. 2). This question of importance will be addressed in future research by solving the three-component mixing model (Eqn. 3) to assess the sensitivity of model to variations in DIC. At this point, the variation in contributions from $Q_{S}$ or $\mathrm{Q}_{\mathrm{B}}$ using different $\mathrm{C}_{\mathrm{B}} / \delta_{\mathrm{B}}$ values may or may not be important because of solving Equations 6 and 7 (where $Q_{R}$, $\mathrm{Q}_{\mathrm{S}}$, and $\mathrm{Q}_{\mathrm{B}}$ are not calculated independently using DIC), and possibly over-estimating the contributions from $Q_{S}$ compared to $\mathrm{Q}_{\mathrm{B}}$.

Of the stored-water component $\left(Q_{p}\right)$, soil water exerted important control on storm-event geochemistry at Blowing Spring (Figs. 3 and 6). The importance of vadose-zone water (either soil or epikarst) has been demonstrated in other karst systems (Doctor et al. 2006; Lee \& Krothe 2001; Lee \& Krothe 2003; Trček et al. 2006). Vadose-zone water is inherently difficult to sample (small volumes, heterogenous, etc.), but this research highlights the importance of considering soil water in mantled karst settings. This is especially important in northwestern Arkansas where the soil zone is impacted by anthropogenic changes in land use, including urbanization and agriculture. Further research at Blowing 
Spring will include analysis of major cation/anion geochemistry in the soil zone and comparison to geochemistry at site BS06, which receives drip water from the soil and epikarst zones. Additionally, the residence and transit times of soil water will be better constrained, to help address questions of mixing water sources along groundwater flow paths.

The relation between the isotopic composition of the gaseous cave atmosphere $\left(\mathrm{CO}_{2}\right)$ and the aqueous cave stream (DIC) is being investigated at Blowing Spring to further understand the variation in DIC concentration and isotopic composition along the cave stream, and how differing values for $\mathrm{C}_{\mathrm{B}} / \delta_{\mathrm{B}}$ change the final results of the two-component and three-component mixing models. Research has shown that the concentration and iso- topic composition of cave- $\mathrm{CO}_{2}$ varies over time (Kowalczk \& Froelich 2010; Pollock et al. 2011; Spötl et al. 2005) so the potential effect of the cave atmosphere on the cave stream will be considered when analyzing these antecedent conditions prior to storm events. Although the two-component hydrograph separation could not be completed using stable isotopes of water $\left(\delta^{2} \mathrm{H}\right.$ and $\left.\delta^{18} \mathrm{O}\right)$, the variation in DIC concentration and isotopic composition between the soil and cave highlights the usefulness of carbon to characterize the geochemistry of karst systems. Future work will expand the mixing models discussed, compare multiple storm events to assess variability in spring response to storm events in the Ozarks, and relate the source-water contributions to changes in water quality.

\section{ACKNOWLEDGMENTS}

This manuscript was greatly improved by the comments from Natasa Ravbar, Tim Kresse, James Petersen, Keith Lucey, and an anonymous reviewer. Funding for this research was provided by the Geological Society of America and the National Speleological Society. This manuscript was developed under STAR Fellowship Grant Number FP917347 awarded by the U.S. Environmental Protection Agency (EPA). It has not been formally reviewed by the EPA. The views expressed in this manuscript are solely those of Katherine J. Knierim, and EPA does not endorse any products or commercial services mentioned in this manuscript. Any use of trade, firm, or product names is for descriptive purposes only and does not imply endorsement by the U.S. Government. The Arkansas Water Resources Center Water Quality Laboratory provided analytical support. Special thanks are given to the Bella Vista Property Owner's Association for use of the research site and non-monetary support and to the Boston Mountain Grotto for mapping Blowing Springs Cave.

\section{REFERENCES}

Adamski, J., Petersen, J., Freiwald, D. \& J. Davis, 1995: Environmental and hydrologic setting of the Ozark Plateaus study unit, Arkansas, Kansas, Missouri, and Oklahoma.- U.S. Geological Survey, Report number: Water Resources Investigation Report 94-4022.

Arkansas Water Resources Center, 2008: AWRC Water Quality Laboratory.- [Online] Available from: http://www.uark.edu/depts/awrc/waterqualitylab. html [Accessed 6th February 2013].

Brahana, J., 1997: Rationale and methodology for approximating spring-basin boundaries in the mantled karst terrane of the Springfield Plateau, northwestern Arkansas.- In: Beck \& Stephenson (eds.) The Engineering Geology and Hydrogeology of Karst Terranes, Balkema, pp. 77-82, Rotterdam.
Burnette, D. \& D. Stahle, 2013: Historical perspective on the dust bowl drought in the central United States.Climatic Change, 116, 479-494.

Buttle, J., 1994: Isotope hydrograph separations and rapid delivery of pre-event water from drainage basins.Progress in Physical Geography, 18, 1, 16-41.

Clark, I. \& P. Fritz, 1997: Environmental Isotopes in Hydrogeology. Lewis Publishers, pp. 328, Boca Raton.

Coplen, T., 1996: New guidelines for reporting stable hydrogen, carbon, and oxygen isotope-ratio data.Geochimica et Cosmochimica Acta, 60, 17, 33593360 .

Craig, H., 1961: Variations in meteoric waters.- Science, 133, 1702-1703.

Daansgard W., 1964: Stable isotopes in precipitation.Tellus, 16, 4, 436-468. 
Davis, R., Brahana, J., \& J. Johnston, 2000: Ground water in northwest Arkansas: Minimizing nutrient contamination from non-point sources in karst terrane.Arkansas Water Resources Center, Report Number: MSC-288.

Doctor, D., Alexander, E., Petric, M., Kogovsek, J., Urbanc, J., Lojen, S. \& W. Stichler, 2006: Quantification of karst aquifer discharge components during storm events through end-member mixing analysis using natural chemistry and stable isotopes as tracers.- Hydrogeology Journal, 14, 1171-1191.

Gehre, M., Geilmann, H., Richter, J., Werner, R., \& W. Brand, 2004: Continuous flow ${ }^{2} \mathrm{H} /{ }^{1} \mathrm{H}$ and ${ }^{18} \mathrm{O} /{ }^{16} \mathrm{O}$ analysis of water samples with dual inlet precision.Rapid Communications in Mass Spectrometry, 18, 2650-2660.

Gibson. J., Briks, S. \& T. Edwards, 2008: Global prediction of $\delta_{\mathrm{A}}$ and $\delta^{2} \mathrm{H}-\delta^{18} \mathrm{O}$ evaporation slopes for lakes and soil water for seasonality.- Global Biogeochemical Cycles, 22, 1-12.

Harvey, F., 2001: Use of NADP archive samples to determine isotope composition of precipitation: characterizing the meteoric input function for use in ground water studies.- Ground Water, 39, 3, 380390.

Harvey, F. \& J. Welker, 2000: Stable isotopic composition of precipitation in the semi-arid north-central portion of the US Great Plains.- Journal of Hydrology, 238, 90-109.

Iqbal M. \& N. Krothe, 1995: Infiltration mechanisms related to agricultural waste transport through the soil mantle to karst aquifers of southern Indiana, USA.- Journal of Hydrology, 164, 171-192.

Jones, J., Sudicky, E., Brookfield, A. \& Y. Park, 2006: An assessment of the tracer-based approach to quantifying groundwater contributions to streamflow.Water Resources Research, 42, 1-15.

Kendall, C., McDonnell, J. \& W. Gu, 2001: A look inside 'black box' hydrograph separation models: a study at the Hydrohill catchment.- Hydrological Processes, 15, 1877-1902.

Knierim, K., 2009: Seasonal variation of carbon and nutrient transfer in a northwestern Arkansas cave.- MS thesis. The University of Arkansas, pp. 141.

Kowalczk, A. \& P. Froelich, 2010: Cave air ventilation and $\mathrm{CO} 2$ outgassing by radon-222 modeling: how fast do caves breathe?.- Earth and Planetary Science Letters, 289, 209-219.

Laincz, J., 2011: Investigation of Nitrate Processing in the Interflow Zone of Mantled Karst, Northwestern Arkansas.- U. S. Geological Survey, Report Number: Scientific Investigations Report 2011-5020, 75-83.
Lakey, B. \& N. Krothe, 1996: Stable isotopic variation of storm discharge from a perennial karst spring, Indiana.- Water Resources Research, 32, 721-731.

Lee, E. \& N. Krothe, 2001: A four-component mixing model for water in a karst terrain in south-central Indiana, USA: using solute concentration and stable isotopes as tracers.- Chemical Geology, 179, 129143.

Lee, E. \& N. Krothe, 2003: Delineating the karstic flow system in the upper Lost River drainage basin, south central Indiana: using sulphate and $\delta^{34} \mathrm{~S}_{\mathrm{SO} 4}$ as tracers.- Applied Geochemistry, 19, 145-153.

Long., A., 2009: Hydrograph separation for karst watersheds using a two-domain rainfall-discharge model.- Journal of Hydrology, 364, 249-256.

Luhman, A., Covington, M., Alexander, S., Chai, S., Schwartz, B., Groten, J. \& E. Alexander, 2012: Comparing conservative and nonconservative tracers in karst and using them to estimate flow path geometry.- Journal of Hydrology, 448-449, 201-211.

Mahler, B. \& B. Garner, 2009: Using nitrate to quantify quick flow in a karst aquifer.- Ground Water, 47, 3, 350-360.

Merlivat, L. \& J. Jouzel, 1979: Global climatic interpretation of the deuterium-oxygen 18 relationship for precipitation.- Journal of Geophysical Research, 84, C8, 5029-5033.

National Atmospheric Deposition Program, 2007: National Trends Network Data, Annual PrecipitationWeighted Means.- [Online] Available from: http:// nadp.sws.uiuc.edu/NTN/ntnData.aspx [Accessed $4^{\text {th }}$ February 2013].

National Oceanic and Atmospheric Administration, 2009: Arkansas Northwest Division 01, 1895-2009.[Online] Available from: http://www7.ncdc.noaa. gov/CDO/CDODivisionalSelect.jsp [Accessed $3^{\text {rd }}$ March 2010].

Natural Resources Conservation Service, United States Department of Agriculture, 2012: Web Soil Survey: Custom Soil Resource Report for Benton County, Arkansas.- [Online] Available from: http://websoilsurvey.nrcs.usda.gov/. [Accessed 20 $0^{\text {th }}$ January 2013].

Nelson, S., 2000: A simple, practical methodology for routine VSMOW/SLAP normalization of water samples analyzed by continuous flow methods.Rapid Communications in Mass Spectrometry, 14, 12, 1044-1046.

Ogunkoya, O. \& A. Jenkins, 1993: Analysis of storm hydrograph and flow pathways using a three-component hydrograph separation model.- Journal of Hydrology, 142, 71-88. 
Panno, S., Hackley, K., Hwang, H., \& W. Kelly, 2001: Determination of the sources of nitrate contamination in karst springs using isotopic and chemical indicators.- Chemical Geology, 179, 113-128.

Patricola, C. \& K. Cook, 2013: Mid-twenty-first century warm season climate change in the Central United States. Part I: regional and global model predictions.- Climate Dynamics, 40, 551-568.

Peterson, E., Davis, R., Brahana, J. \& H. Orndorff, 2002: Movement of nitrate through regolith covered karst terrane, Northwest Arkansas.- Journal of Hydrology, 256, 35-47.

Pollock, E., Knierim, K. \& P. Hays, 2011: Seasonal carbon dynamics in a northwestern Arkansas cave: linking climate and cave conditions.- U. S. Geological Survey, Report Number: Scientific Investigations Report 2011-5020, 37-43.

Raeisi, E., Groves, C. \& J. Meiman, 2007: Effects of partial and full pipe flow on hydrochemographs of Logsdon river, Mammoth Cave Kentucky USA.- Journal of Hydrology, 337, 1-10.

Rantz, S., 1982: Measurement and Computation of Streamflow: Volume 1. Measurement of Stage and Discharge.- U.S. Geological Survey, Report Number: Geological Survey Water-Supply Paper 2175.

Rice, K. \& G. Hornberger, 1998: Comparison of hydrochemical tracers to estimate source contributions to peak flow in a small, forested, headwater catchment.- Water Resources Research, 34, 7, 17551766.

Simeral, D., 2013: U.S. Drought Monitor: January 15, 2013.- [Online] Available from: http://www. droughtmonitor.unl.edu/archive.html [Accessed $23^{\text {rd }}$ January 2013].

Simpkins, W., 1995: Isotopic composition of precipitation in central Iowa.- Journal of Hydrology, 172, 185-207.
Sklash, M., \& R. Farvolden, 1979: The role of groundwater in storm runoff.- Journal of Hydrology, 43, 45-65.

Sklash, M., Farvolden, R., and P. Fritz, 1976: A conceptual model of water response to rainfall, developed through the use of oxygen-18 as a natural tracer.Canadian Journal of Earth Sciences, 13, 271-283.

Spötl, C., Fairchild, I. \& A. Tooth, 2005: Cave air control on dripwater geochemistry, Obir Caves (Austria): Implications for speleothem deposition in dynamically ventilated caves.- Geochimica et Cosmochimica Acta, 69, 2451-2468.

St-Jean, G., 2003: Automated quantitative and isotopic $\left({ }^{13} \mathrm{C}\right)$ analysis of dissolved inorganic carbon and dissolved organic carbon in continuous-flow using a total organic carbon analyser.- Rapid Communications in Mass Spectrometry, 17, 419-428.

Taylor, D. S., Goodwin, D. P., Bitting, C. J., Handford, R., \& M., Slay, 2009: The Ozark Plateaus: Arkansas.- In: Palmer, A. N. \& M. V. Palmer (eds.) Caves and Karst of the USA. National Speleological Society, Inc., pp. 172-178, Huntsville, Alabama.

Tetzlaff, D., Soulsby, C., Hrachowitz, M., \& M. Speed, 2011: Relative influence of upland and lowland headwaters on the isotope hydrology and transit times of larger catchments.- Journal of Hydrology, 400, 438-447.

Trček, B., Veselic, M., and J. Pezdic, 2006: The vulnerability of karst springs: a case study of the Hubelj Spring (SW Slovenia).- Environmental Geology, 49, 865-874

U.S. Department of Agriculture, 2007: State Fact Sheets: Arkansas.- [Online] Available from: http://www. ers.usda.gov/data-products/state-fact-sheets/statedata.aspx? StateFIPS $=05 \&$ StateName $=$ Arkansas $\#$ P6 6692c6d09db47faa4f648925911c323 2 657iT24R0 $\underline{\mathrm{x} 0}$ [Accessed 23 ${ }^{\text {rd }}$ January 2013. 